\title{
Joint impact of ERP systems and non financial performance indicators on corporate financial performance: Evidence from French listed companies
}

\author{
Ahmed Kouki \\ C H R O N I C L E \\ Article history: \\ Received September 18, 2014 \\ Accepted 9 December 2014 \\ Available online \\ December 92014 \\ ERP systems \\ Non Financial performance \\ Indicators \\ Integrated information systems \\ $T Q M$ \\ $B S C$
}

Faculty of Economics and management of Sfax, Sfax, Tunisia

\begin{abstract}
A B S T R A C T
This paper aims to examine the joint impact of Enterprise Resource Planning systems (ERP systems) and Non Financial Performance Indicators (NFPI) on corporate financial performance. Our study is based on a comparative analysis between firms that adopt ERP only, firms that use NFPI only and firms that combining both strategies (ERP and NFPI) during the period from 2001 to 2006. The implementation process remains highly uncertain. In fact, the use of Non Financial performance indicators is an important determinant of corporate financial performance. At the operational level, combining ERP systems with NFPI reflects a long-term business strategy to improve business process. In summary, the ERP and NFPI literatures demonstrate the vital importance of aligning business process, information technologies and key performance indicators with the strategic objectives of the firm. Results support the hypothesis in which firms that combining ERP and NFPI have significantly higher ROA than either ERP-only or NFPI-only firms.
\end{abstract}

\section{Introduction}

This paper investigates whether the corporate financial performance increases following the jointly adoption of Enterprise Resource Planning (ERP) systems and Non Financial Performance Indicators (NFPI). In the last two decades, business environment appreciates the importance of information for the decision-making and the improvement of corporate performance (Drucker, 1995). The advent of information and communication technologies (ICT) enhances the business process by providing organizations with easy and fast access to relevant and real-time information needed to implement the appropriate strategy. Therefore, managers should revise their approaches to evaluate performance. Furthermore, excessive competitiveness and uncertain environment affect performance measurement systems. Today's, the performance valuation is based not only on financial numbers, but also on nonfinancial data (Eccles, 1991). Prior studies show that non financial indicators are an important 
determinant of corporate financial performance (Kaplan and Norton, 1992, 1996; Ittner and Larcker, 1995, 1998; Banker et al., 2000; Said et al., 2003; Wier et al. 2005; Wiersma, 2008).

Hunton et al. (2003) argue that managers concerned to have a management oriented towards the future must implement an integrated information system that will used to trace the past. There are many companies those already vacant traditional information systems to implement integrated information systems, such as ERP systems. Kumar et al. (2002) define the ERP as a "computer application that aims to ensure the integration of the management of the business processes by automating the flow of materials, information and financial resources of the company within any functions in the organization by using a unique database". Therefore, ERP systems are management tools that provide the integration within the organization. Laframboise and Reyes (2005) indicate that ERP as well as an opportunity to reengineering through its ability to track and monitor transactions. Woo (2007) suggests that organizations invest in ERP systems to gain a variety of operational, managerial and strategic benefits. The impact of ERP adoption on financial performance is the main objective of several studies management accounting and information systems (Poston and Grabski, 2001; Hayes et al., 2001; Hunton et al., 2003; Hyvönen, 2007; Wang \& Zhang, 2006; Wier et al., 2007).

ERP system is a client-server architecture that ensures the decision-making. Grunland and Malmi (2002) argue that ERP is an agent of change within the organization. The implementation of such systems is a long-term strategic investment. Indeed, the use of non-financial performance indicators (NFPI) motivates managers to consider the importance of the behavioural aspect through the organization in the process of highlighting the performance measures (Kaplan \& Norton, 1992). In the area of NFPI, prior literature focuses on Balanced Scorecard (BSC), Total Quality Management (TQM), Customer Satisfaction (CS), strategic human resource management and technological innovation. Furthermore, the joint adoption of ERP systems and NFPI is a strategic decision that aims to improve the company's financial performance (Wier et al., 2007).

This study contributes to the extant literature by combining two long-term strategic investments and investigates whether the jointly effect of ERP systems and NFPI increases the corporate financial performance. Our empirical analysis is based on comparative study between ERP-firms, NFPI-firms and firms that jointly adopt ERP and NFPI. The sample consists of 102 French listed companies.

The remainder of the paper is organized as follows. In the next section we describe the literature review and hypotheses development. Section 3 interested about research design. Section 4 presents results and discussion. Section 5 offers conclusions and future research.

\section{Literature review and hypotheses development}

\subsection{ERP systems and financial performance}

ERP systems are a major technology investment (Hendricks et al., 2007). The implementation of ERP systems ensures the integration between the business processes and information technologies in a set of synchronized procedures and applications that allow to gain a competitive advantage (Laframboise \& Reyes, 2005; Wier et al., 2007). Furthermore, the ERP is expected to improve the company's financial performance (Davenport, 1998; Akkermans et al., 2003). Brignall and Ballantine (2004) argue that the ERP adoption is a strategic choice that considers the organization's life cycle complexity and the characteristics of the internal and external business environment.

Jensen and Meckling (1976) suggest that the disparity of interests and the information asymmetry between the principal and the agent enhance the conflict of interest into the organization. To reduce agency costs that affect the company's performance, managers should be able to establish a strategic management system. Wang and Zhang (2007) showed that the ERP system reduce information asymmetry.

ERP systems are intended to improve organizational financial performance (Kallunki et al., 2011). Several studies examine the impact of ERP systems on financial performance (Hayes et al., 2001; 
Poston \& Grabski, 2001; Hunton et al., 2003; Hyvönen, 2007; Wang \& Zhang, 2006; Wier et al., 2007; Kallunki et al., 2011).

The use of ERPS may result in production and quality improvements in key business areas, such as product reliability, customer service, and knowledge management. Hayes et al. (2001) indicate that the announcement of the implementation of ERP systems has a positive effect on the investors' reaction in the financial market. Therefore, the ERP adoption increases the firm's value and improves its performance. In the same field, Hunton et al. (2003) argue that the company's decision to adopt an ERP system has a significant effect on the strategic behavior of investors. They add that the use of ERP may improve product reliability, customer satisfaction and total quality management. Poston and Grabski (2001) investigate the impact of ERP on the financial performance through a sample of firms that adopt the ERP systems. They found no effect on financial performance.

Hunton et al. (2003) conduct a comparative study between 63 ERP adopters and 63 non adopters firms. The authors use the Return On Asset (ROA), Return On Investment (ROI), Return On Sale (ROS) and Asset Turnover (ATO) as a proxy of financial performance. They show that non-ERP firms experience decreases the performance; nonetheless, ERP adoption improves the financial performance. Overall results find that the ERP adoption has a positive and significant effect on the company's financial performance. Similarly, Wier et al. (2007) suggest that the implementation of ERP systems increases the firm's financial performance. They argue that the ERP systems are at the origin of competitive advantage. Therefore, the first hypothesis $\mathbf{H 1}$ is presented as follows:

Hypothesis H1: The ERP adoption has a positive and significant effect on the company's financial performance.

\subsection{Non-financial performance indicators (NFPI) and financial performance}

Competitive advantage originates and grows from relationships, competences and knowledge (Kaplan \& Norton, 1992). Eccles (1991) argues that non-financial performance indicator is the keystone of strategic management systems. Several studies investigate the rule of using NFPI in the companies' business process (Hughes, 2000; Banker et al., 2000; Ittner \& Larcker, 1995; Ittner \& Larcker, 1998; Said et al., 2003; Hassabelnaby et al., 2005; Kaplan \& Norton, 1992, 1995; Behin \& Riley, 1999; Wier et al., 2007; Kallunki et al., 2011). For many companies, management control systems are built based on financial measures. Thus, the emphasis most companies set on financial measures leaves a gap between the development of a strategy and its implementation. Consequently, managers have to relate the financial indicators and non-financial performance indicators to linking long-term strategic objectives with short-term actions (Kaplan \& Norton, 1996). Wier et al. (2007) indicate that the NFPI contribute to align management process, strategy and performance. The use of NFPI reflects a longterm business strategy (Ittner et al., 1997). Prior literature investigates whether the NFPI increase the companies' financial performance (Chenhall, 1997; Perera et al., 1997; Ittner \& Larcker, 1998; Bihen \& Riley, 1999; Said et al., 2003 Anderson et al., 2007).

Amir and lev (1996) demonstrate that non-financial performance measures are more informative to investors than financial accounting measures in the wireless communication industry. Similarly, Riley et al. (2003) find that non-financial performance metrics is more value relevant than traditional accounting and financial metrics in the airline industry. Chenhall (1997) examines the impact of TQM on performance and show that the implementation of TQM has a positive and significant impact on the organizational performance. Anderson et al. (1997); Perera et al. (1997); Behin and Riley (1999) emphasize the importance of customer satisfaction in the improvement of the company's performance. Ittner and Larcker (1998) suggest, via a study in which measure the influence of customer satisfaction on the company's market value, that the use of non-financial measures improves the firm's stock returns. Said et al. (2003) and Wier et al. (2007) associate the use of NFPI and the company's performance and found that the NFPI is positively and significantly related to financial performance. 
Prior literature demonstrates that the use of non financial information is at the origin of sustainable competitive advantage, improves the long term financial performance and linking long-term strategic objectives with short-term actions. Based on prior studies, our second hypothesis $\mathbf{H 2}$ is presented as follows:

Hypothesis H2: The use of non-financial performance indicators has a positive and significant effect on the company's financial performance.

\subsection{Combining ERP and NFPI}

Literature in managerial accounting and information systems stress the great importance to combining strategies. The combination ensures the strategic alignment of business process and information technology with the firm's long-term strategic objectives (Kaplan and Norton, 1996). The combination of ERP systems with the non financial performance indicators (NFPI) is a response to the needs of managers to have a high degree of monitoring into the operational, managerial and strategic level. Indeed, by combining the ERP and NFPI, managers aim to mitigate the information asymmetry and to enhance the corporate financial performance. The effect of the joint adoption of ERP systems and NFPI on corporate performance has been validated empirically by Laframboise and Reyes (2005) and Wier et al. (2007). Findings found that the combined adoption of ERP systems and NFPI is positively and significantly related to financial performance. This result is more relevant than the ERP adoption only or the use of NFPI only. Thus, our third hypothesis $\mathbf{H 3}$ is presented as follows:

Hypothesis H3: The joint adoption of ERP systems and NFPI has a positive and significant effect on the company's financial performance.

\section{3. research design}

\subsection{Sample and data}

Table 1 reports the sample selection. Data was collected from the web-site www.amf-france.org by examining the annual reports of firms. Our sample consists of French listed companies for the period from 2001 to 2006. We divided the sample into three sub-samples. The sub-sample 1 contains 31 French listed companies which adopt ERP only. The sub-sample 2 contains 33 French listed companies that use non-financial performance indicators (NFPI). The sub-sample 3 consists of 38 companies that jointly adopt ERP and NFPI.

Table 1

Sample selection

\begin{tabular}{llll}
\hline & $\begin{array}{l}\text { Sub-sample1 } \\
\text { (ERP-Firms) }\end{array}$ & $\begin{array}{l}\text { Sub-sample2 } \\
\text { (NFPI-Firms) }\end{array}$ & $\begin{array}{l}\text { Sub-sample3 } \\
\text { (ERP and NFPI firms) }\end{array}$ \\
\hline Firms & 31 & 33 & 38 \\
Firm-year observations & 186 & 198 & 228 \\
\hline
\end{tabular}

\subsection{Models and variables definitions}

\subsubsection{Model of Wier et al. (2007)}

Consistent with prior study of Wier et al. (2007), we develop our econometric models. Authors use the return on assets (ROA) as a proxy of company's financial performance. The Wier et al. model is presented as follows:

$$
\begin{aligned}
& R O A_{i t}=\beta_{10}+\beta_{11} \text { ERP }[\text { FIT_ERP }]+\beta_{12} \text { NFPI }\left[\text { FIT }{ }_{-} \text {NFPI }\right]+\beta_{13} I N T\left[\text { FIT }{ }_{-} \text {INT }\right]+ \\
& \beta_{14} I R O A+\beta_{15} L E V+\beta_{16} \text { SIZE }+\beta_{17} \text { GROWTH }+\beta_{18} \text { ACTVOL }+\varepsilon_{i t}
\end{aligned}
$$

where: 
$R O A$ : Return On Assets of firm $i$ at time $t$; ERP: Implementation of ERP by firm $i$ at time $t$; NFPI: Use of non financial performance indicators of firm $i$ at time $t$; INT: Interaction variable (ERP $\times$ NFPI) of firm $i$ at time $t ; L E V$ : Measured using debt-equity ratio of firm $i$ at time $t ; S I Z E$ : Size measured as the $\log$ of total assets of firm $i$ at time $t$; GROWTH: Growth of firm $i$ at time $t$; IROA: The industry average of change in ROA of firm $i$ at time $t$; ACTVOL: The standard deviation of annual return on assets over the previous 5 years of firm $i$ at time $t$; $\varepsilon$ : Error term.

\subsubsection{Econometric modeling}

We estimate the following models to test, respectively, the hypotheses $\mathrm{H} 1, \mathrm{H} 2$ and $\mathrm{H} 3$ :

$$
\begin{aligned}
& R O A_{i t}=\beta_{10}+\beta_{11} E R P_{i t}+\beta_{12} L E V_{i t}+\beta_{13} S_{I Z E_{i t}}+\beta_{14} G R O W T H_{i t}+\varepsilon_{i t} \\
& R O A_{i t}=\beta_{10}+\beta_{11} N F P I_{i t}+\beta_{12} L E V_{i t}+\beta_{13} S I Z E_{i t}+\beta_{14} G R O W T H_{i t}+\varepsilon_{i t} \\
& R O A_{i t}=\beta_{10}+\beta_{11} E R P_{i t}+\beta_{12} N F P I_{i t}+\beta_{13} I N T+\beta_{14} L E V_{i t}+\beta_{15} S I Z E_{i t}+\beta_{16} G R O W T H_{i t}+\varepsilon_{i t}
\end{aligned}
$$

\subsubsection{Variables description and measurement}

\subsubsection{Dependent variable: Financial performance}

The company's financial performance measure has always been very sensitive in empirical research. Indeed, several measures of performance were developed in the literature. In our study, we retain the Return On Assets (ROA) as a proxy for the variable "financial performance":

$$
R O A=\frac{\text { Netincome }}{\text { TotalAsset } s}
$$

\subsubsection{Independent variables}

a. ERP systems adopt

The ERP system is a dummy variable that takes the value of " 1 " if the company adopt it and " 0 " otherwise.

\section{b. Use of non-financial performance indicators (NFPI)}

The NFPI is a dummy variable that takes the value of " 1 " if the company use it and " 0 " otherwise.

c. Interaction variable (ERP $x$ NFPI)

To examine the joint impact of ERP adoption and use of non-financial performance indicators on financial performance we use an interaction variable (ERP x NFPI). This variable takes the value of " 1 " if the company adopts the two variables at same time and " 0 " otherwise.

\subsubsection{Control variables}

Control variables are leverage, size and growth. Leverage is measured by the Debt to Equity ratio. The size of the company is measured by the natural logarithm of total assets. The Growth is measured by divided the market value of equity plus book value of debt by book value of assets at the beginning of the year.

\section{Multivariate analysis}

In the multivariate analysis, we run two econometric tests namely, the homogeneity test and the Hausman test for the three equations Eq. (1), Eq. (2) and Eq. (3).

\subsection{Homogeneity test}

Table 2 presents the results of the homogeneity test. The existence of specific effects leads to choose the estimation methods. If it's a fixed effect, we retained the within method, if it's a random effect we 
retain the GLS method. In counter-point, if there is no specific effect, we use the OLS method. The run of this test to the three econometric models shows the existence of specific effects.

Table 2

Homogeneity test

\begin{tabular}{lcccc}
\hline Equations & $F \rightarrow\left(\mathrm{N}-1, \mathrm{~T}^{*} \mathrm{~N}-\mathrm{N}-\mathrm{K}\right)$ & $F$-tabulate at $5 \%$ & $F$-calculate & Specific effects \\
\hline Eq. (1) & $(30,151)$ & 1.70 & 3.47 & Exist \\
Eq. (2) & $(32,161)$ & 1.67 & 7.83 & Exist \\
Eq. (3) & $(37,168)$ & 1.62 & 9.64 & Exist \\
\hline
\end{tabular}

\subsection{Hausman test}

Results of Hausman test are shown in Table 3. To specify the types of retained effects (are fixed or random effects) we computing the Hausman test. This test applied to the three models suggests that the retained effects for all equations are random effects. Then, we use the GLS regression to the Eq. (1), Eq. (2) and Eq. (3).

Table 3

Hausman test

\begin{tabular}{lcccc}
\hline Equations & $\mathrm{K}^{*}$ & $\chi 2(\mathrm{k})$ à $5 \%$ & Hausman test & $\mathrm{EF}^{*} \mathrm{EA}^{* *}$ \\
\hline Eq. (1) & 4 & 9.488 & 1.999 & EA \\
Eq. (2) & 4 & 9.488 & 0.291 & EA \\
Eq. (3) & 6 & 12.592 & 1.641 & EA \\
\hline
\end{tabular}

${ }^{*} \mathrm{~K}$ : Number of independent variables; ${ }^{* *} \mathrm{EF} / \mathrm{EA}$ : Fixed effects or random effects.

${ }^{* *}$ If $\chi^{2}(\mathrm{k})>\chi^{2}$ (Hausman) $\Longrightarrow \mathbf{E A}$; If $\chi^{2}(\mathrm{k})<\chi^{2}$ (Hausman) $\Longrightarrow \mathbf{E F}$

\subsection{Results and discussion}

\subsubsection{ERP and financial performance}

To test our first hypothesis H1, we use GLS multivariate regression model. Table 4 reports the results of an analysis regressing ROA on ERP. Our multiple regressions want to investigate the effects of ERP adoption on financial performance. Following the estimation of the equation Eq. (A.1), we find that the adjusted R-square is in the order of 0.1718 . This result indicates that the explanatory variables contribute to the explanation of the ROA (proxy of financial performance) at the proportion of $17.18 \%$ and the model is globally significant $(F$-statistic $=3.474 ; p$-value $=0.000)$. Then, we observe that the coefficient of ERP is positive and statistically significant at the $5 \%$ level $\left(\beta_{1}=0.039 ; t\right.$-test $\left.=2.30\right)$. This matter stipulates that a one-unit increase in the ERP investment means an improvement of the financial performance by 0.039 units. Among the control variables, the coefficient of LEV is negative and not significant. The SIZE has a positive and significant coefficient at the $5 \%$ level $\left(\beta_{3}=0.025 ; t\right.$ test $=2.579)$. Indeed, the coefficient of the variable GROWTH is negative and statistically not significant.

Overall results stress the vital importance of the implementation of ERP systems in the organization. ERP adoption supports business process improvements and enhances decision-making and financial performance of French listed companies. Thus, presented by its characteristics such as integration, standardization, and centralization, the implementation of ERP systems is appreciated by managers since it improves the management control systems and mitigates the information asymmetry. Among the variable SIZE, findings demonstrate that the company's size is an important determinant of the strategic choice to invest in ERP projects a fact that the ERP implementation cost is too expensive. The absence of the relationship between leverage (LEV) and financial performance may be explained by the fact that innovative companies consider that the adoption of an integrated information systems is a vital investment that need funding with debt. Results confirm our hypothesis H1.Our findings are consistent with prior studies of Hunton et al. (2003) and Wier et al. (2007). 
Table 4

GLS regression model (Eq. (A.1)) with ROA

\begin{tabular}{lccc}
\hline Variables & Coefficient & $t$-test \\
\hline Intercept & -0.38 & & $(\mathbf{- 2 . 0 3})^{* * *}$ \\
ERP & 0.039 & & $(\mathbf{2 . 3 0})^{* *}$ \\
LEV & $-2.9910^{-5}$ & & $(-0.21)$ \\
SIZE & 0.025 & & $(\mathbf{2 . 5 7 9})^{* *}$ \\
GROWTH & -0.01 & & $(-0.88)$ \\
\hline $\mathrm{R}^{2}(\%)$ & & 17.18 & \\
Durbin-Watson & & 2.09 & \\
F-statistic & & 3.474 & \\
Prob_(F-statistic) & & 0.000 & \\
Firm-year observations (N) & & 186 & \\
\hline$* * * * 0.01 ; *$ & & \\
\hline
\end{tabular}

$\frac{\text { Firm-year observations }(\mathrm{N})}{{ }^{* * *} \mathrm{p}<0.01 ;{ }^{* *} \mathrm{p}<0.05 ;{ }^{*} \mathrm{p}<0.1}$

\subsubsection{NFPI and financial performance}

To test our second hypothesis H2, we use GLS multivariate regression model. Table 5 presents the findings of an analysis regressing ROA on NFPI. Our multiple regressions want to investigate the effects of the use of NFPI on financial performance. Following the estimation of the equation Eq. (A.2), we find that the adjusted R-square is in the order of 0.5513 . This result indicates that the explanatory variables contribute to the explanation of the ROA at the proportion of $55.13 \%$ and the model is globally significant $(F$-statistic $=7.835 ; p$-value $=0.000)$. Then, we observe that the NFPI has a positive and statistically significant coefficient at the $5 \%$ level $\left(\beta_{1}=0.010 ; t\right.$-test $\left.=2.10\right)$. This matter stipulates that a one-unit increase in the use of NFPI reflects an improvement of the financial performance by 0.010 units. Among the control variables, the coefficient of LEV is negative and not significant. The SIZE has a positive and significant coefficient at the $1 \%$ level $\left(\beta_{3}=0.021 ; t\right.$-test $\left.=2.84\right)$. Then, the coefficient of the variable GROWTH is positive and statistically significant at $5 \%$ level $\left(\beta_{4}=0.025 ; t\right.$ test $=2.33$ ).

Overall results indicate the vital importance of the use of NFPI in the organization. In fact, the nonfinancial indicators reflect a long-term business strategy. By the implementation of NFPI, managers have to relate the financial indicators and non-financial indicators with the aim to ensure the connection between long-term strategic objectives with short-term actions. Among the variable SIZE, findings demonstrate that the company's size is an important determinant of the strategic choice to use NFPI in management process. Considering the positive and significant relationship between GROWTH and financial performance, it is worth noting that the use of NFPI enhances the company's growth rate which is reflected on the company's financial performance. Findings confirm our hypothesis H2.Our results are consistent with prior studies of Laframboise and Reyes (2005) and Wier et al. (2007).

Table 5

GLS regression model (Eq. (A.2)) with ROA

\begin{tabular}{|c|c|c|}
\hline Variables & Coefficient & t-statistique \\
\hline Intercept & -0.361 & $-2.42^{* * *}$ \\
\hline NFPI & 0.010 & 2.10 ** \\
\hline LEV & -0.000 & -0.89 \\
\hline SIZE & 0.021 & $2.84^{* * * *}$ \\
\hline GROWTH & 0.025 & $2.33^{* *}$ \\
\hline $\mathrm{R}^{2}(\%)$ & \multicolumn{2}{|c|}{55.13} \\
\hline Durbin-Watson & \multicolumn{2}{|c|}{2.36} \\
\hline F-statistic & \multicolumn{2}{|c|}{7.835} \\
\hline Prob_(F-statistic) & \multicolumn{2}{|c|}{0.000} \\
\hline Firm-year observations (N) & \multicolumn{2}{|c|}{198} \\
\hline
\end{tabular}

${ }^{* * *} \mathrm{p}<0.01 ;{ }^{* *} \mathrm{p}<0.05 ;{ }^{*} \mathrm{p}<0.1$ 


\subsubsection{Interaction variable (ERP $x$ NFPI) and financial performance}

To test our hypothesis H3, we use GLS multivariate regression model. Table 6 summarizes the results of an analysis regressing ROA on the interaction between ERP and NFPI. Our multiple regressions want to investigate the effects of the joint adoption of ERP systems and the use of NFPI on financial performance. Following the estimation of the equation Eq. (3), we find that the adjusted R-square is in the order of 0.3606 . This result indicates that the explanatory variables contribute to the explanation of the ROA at the proportion of $36.06 \%$ and the model is globally significant $(F$-statistic $=9.643 ; p$-value $=0.000)$. Then, we observe that the ERP has a positive and statistically significant coefficient at the $5 \%$ level $\left(\beta_{1}=1.30 ; t\right.$-test $\left.=2.06\right)$. The coefficient of ERP is significantly higher in the Eq. (3) than the coefficient of this variable in the Eq. (1) and the difference is statistically significant at the $1 \%$ level. Then, following the estimation of Eq. (3), the coefficient of NFPI is positive and statistically significant at the $1 \%$ threshold $\left(\beta_{2}=1.008 ; t\right.$-test $\left.=3.05\right)$. The coefficient of the variable NFPI in the Eq. (3) is larger than this coefficient in the Eq. (2) and the difference is statistically significant at the 5\% threshold. The coefficient of the interaction between ERP and NFPI is positively and significantly related to the ROA $\left(\beta_{3}=1.96\right.$; $t$-test $\left.=3.63\right)$. Among the control variables, the coefficient of LEV is negative and not significant. The SIZE has a positive and significant coefficient at the $5 \%$ level. Then, the coefficient of the variable GROWTH is positive and statistically not significant. Overall results support our hypothesis H3 stipulating that the joint adoption of ERP systems and NFPI has a positive and significant effect on the company's financial performance. Findings are consistent with the studies of Hunton et al. (2003); Laframboise and Reyes (2005); Wier et al. (2007).

\section{Table 6}

GLS regression model (Eq. (A.3)) with ROA

\begin{tabular}{|c|c|c|}
\hline Variables & Coefficients & $t$-test \\
\hline Intercept & -3.54 & $(-0.12)$ \\
\hline ERP & 1.30 & $(2.06)^{* * *}$ \\
\hline NFPI & 1.008 & $(3.05)^{* * *}$ \\
\hline INT & 1.96 & $(3.63)^{* * * *}$ \\
\hline LEV & -0.01 & $(-0.82)$ \\
\hline SIZE & 0.38 & $(2.53)^{* * *}$ \\
\hline GROWTH & 0.03 & $(1.01)$ \\
\hline $\mathrm{R}^{2}(\%)$ & & \\
\hline Durbin-Watson & & \\
\hline F-statistic & & \\
\hline Prob (F-statistic) & & \\
\hline Firm-year observations (N) & & \\
\hline
\end{tabular}

\section{Conclusions and future research}

This paper examine whether the joint adoption of ERP systems and non financial performance indicators increases the company's financial performance. Our study is based on a comparative analysis between firms that adopt ERP only, firms that use NFPI only and firms that combining ERP and NFPI during the period from 2001 to 2006. The sample consists of 106 French listed companies. Results show that the ERP adoption only improves the financial performance of French listed companies. In addition, the use of non-financial performance indicators alone increases the firms' financial performance. Whereas, findings suggest that the combination of both strategies is more relevant in the explanation of ROA, as compared to either strategy alone.

Combining ERP systems and non-financial performance indicators provides the advantage to linking the long-term strategic objectives with short-term actions (Kaplan and Norton, 1996). Future research should examine the value relevance of combining strategies in the business process. Indeed, it is vital 
important to associate financial numbers with non-financial data to improve the investors' makingdecision and to understand the complexity of business environment.

\section{References}

Akkermans, H. A., Bogerd, P., Yücesan, E., \& Van Wassenhove, L. (2003). The impact of ERP on supply chain management: exploratory findings from a European Delphi study. European Journal of Operational Research, 146 (2), 284-301.

Amir, E., \& Lev, B. (1996). Value-relevance of non-financial information: the wireless communications industry. Journal of Accounting and Economics, 22(1-3), 3-30.

Anderson, A., \& Muller, R. (2007). Containing transaction costs in ERP implementation through identification of strategic learning projects. Project Management Journal, 38 (2), 84-92.

Banker, R., Potter, G., \& Srinivasan, D. (2000). An empirical investigation of an incentive plan that includes non financial performance measures. The accounting review, 75 (1), 65-92.

Behin, B., \& Riley, R. (1999). Using Nonfinancial Information to Predict Financial Performance: The Case of the U.S. Airline Industry. Journal of Accounting, Auditing and Finance, 14 (1), 29-56.

Brignall, S., \& Ballantine, J. (2004). Strategic Enterprise Management Systems: new directions for research. Management Accounting Research, 15 (2), 225-240.

Chenhall, R.H. (1997). Reliance on manufacturing performance measures, total quality_management and organizational performance. Management Accounting Research, 8 (2), 187-206.

Davenport, T.D. (1998). Cooperative ERP Life-cycle Knowledge Management. Proceedings of the Ninth Australasian Conference on Information Systems. September 29-October 2, Sydney, 227-240.

Drucker, P. F. (1995). The information executives truly need. Harvard Business Review, 73(1), 54-63.

Eccles, R.G. (1991). The performance measurement manifesto. Harvard Business Review, 69(1), 131138.

Grunlund, M., \& Malmi, T. (2002). Moderate impact of ERPS on management accounting: a lag or permanent outcome? Management Accounting Research, 13(3), 299-321.

HassabElnaby, H.R., Said,A.A., \& Wier, B. (2005). The Retention of Nonfinancial Performance Measures in Compensation Contracts. Journal of management accounting research, 17(1), 23-42.

Hayes, D.C., Hunton, J.E., \& Reck, J.L. (2001). Market reaction to ERP implementation announcements. Journal of information systems, 15(3), 3-18.

Hendricks, K.B., Singhal, V.R., \& Stratman, J.K. (2007). The impact of enterprise systems on corporate performance: A study of ERP, SCM, and CRM system implementations. Journal of Operations Management, 25(1), 65-82.

Hughes, K.E. (2000). The value relevance of non financial measures of air pollution in the electric utility industry. The Accounting Review, 75(2), 209-228.

Hunton, J. E., Lippincott, B., \& Reck, J.L. (2003). Enterprise resource planning systems: comparing firm performance of adopters and non adopters. International Journal of Accounting Information Systems, 4(3), 165-184.

Hyvonen, J. (2007). Strategy, performance measurement techniques and information technology of the firm and their links to organizational performance. Management Accounting Research, 18 (3), 343 366.

Ittner, C., \& Larcker, D. (1995). Total Quality Management and the Choice of Information and Reward Systems. Journal of accounting research, 33, 1-35.

Ittner, C., \& Larcker, D. (1998). Are Nonfinancial Measures Leading Indicators of Financial Performance? An Analysis of Customer Satisfaction. Journal of accounting research, 36, 1-36.

Ittner, C.D., Larcker, D.F., \& Rajan, M.V. (1997). The choice of performance measures in annual bonus contracts. Accounting Review, 72(2), 231-55.

Jensen, M., \& Meckling, W. (1976). Theory of the firm: Managerial behavior, agency costs and ownerships structure. The Journal of Financial Economics, 3(4), 305-360. 
Kallunki, J., Laitinen, E.K., \& Silvola, H. (2011). Impact of enterprise resource planning systems on management control systems and firm performance. International Journal of Accounting Information Systems, 12, 20-39

Kaplan, R.S., \& Norton, D.P. (1992). The balanced scorecard measures that drive performance. Harvard Business Review, 70(1), 72-80.

Kaplan, R.S., \& Norton, D.P. (1996). Using the balanced scorecard as a strategic management system. Harvard Business Review, 74(1), 74-86.

Laframboise, K., \& Reyes, F. (2005). Gaining competitive advantage from integrating Enterprise Resource Planning and Total Quality Management. The Journal of Supply Chain Management, 41(3), 49-64.

Perera, S., Harrison, G., \& Poole, M. (1997). Customer-focused manufacturing strategy and the use of operations-based non-financial performance measures: a research note. Accounting, Organization and Society, 22(6), 557-572.

Poston, R., \& Grabski, S. (2001). Financial impacts of enterprise resource planning implementations. International Journal of Accounting Information Systems, 2(4), 271-294.

Quattrone, P., \& Hopper, T. (2001). What does organizational change mean? Speculations on a taken for granted category. Management Accounting Research, 12(4), 403-435.

Riley, R., Pearson, T., \& Trompeter, G. (2003). The value relevance of non-financial performance variables and accounting information: the case of the airline industry. Journal of Accounting and Public Policy, 22, 231-254.

Said, A. (2003). An Empirical Investigation of the Performance Consequences of Nonfinancial Measures. Journal of management accounting research, 15(1), 193-223.

Wang, L., Zhang, J., \& Liao, Q. (2007). A Principal-Agent Perspective on ERP Implementation Decisions An Empirical Analysis Based on Chinese Listed Companies. http://ssrn.com/.

Wier, B., Hunton, J., \& Hassabelnaby, H. R. (2007). Enterprise resource planning systems and nonfinancial performance incentives: The joint impact on corporate performance. International Journal of Accounting Information Systems, 8 (3), 165-190.

Wier, B., McEwen, R. A., \& Hunton, J. E. (2005). The Reaction of Financial Analysts to Enterprise Resource Planning (ERP) Implementation Plans. Journal of Information Systems, 16(1), 31-40.

Wiersma, E. (2008). An exploratory study of relative and incremental information content of two nonfinancial performance measures: Field study evidence on absence frequency and on-time delivery. Accounting, Organizations and Society, 33(2-3), 249-265.

Woo, H.S. (2007). Critical success factors for implementing ERP: the case of a Chinese electronics manufacturer. Journal of Manufacturing Technology Management, 18(4), 431-442. 